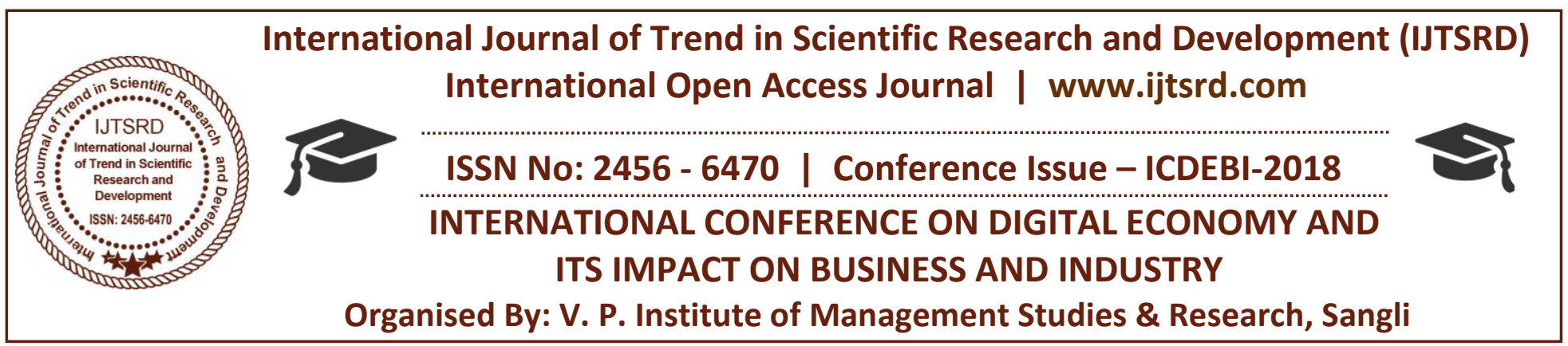

\title{
Digitalisation in The Banking Sector
}

\author{
Laxmikanthanayaka T. $\mathrm{O}^{1,2}$, Prof. Laxmana $\mathrm{P}^{3}$ \\ ${ }^{1}$ Research Scholar, Department of Studies and Research in Commerce, Davangere University, Karnataka, India \\ ${ }^{2}$ Asst. Professor, KLE's Basavaprabhu Kore College, Chikodi, Belagavi Dist, Karnataka, India \\ ${ }^{3}$ Chairman and Research Supervisor, Department of Studies and Research in Commerce, \\ ${ }^{3}$ Davangere University, Karnataka, India
}

\begin{abstract}
It was only in the late 1980s that Indian banks took to computer is at ion seriously. They had to improve customer service and tone up book-keeping and MIS reporting. Their large customer base (in terms of numbers) was mostly comprised of "low balance" accounts. An effective but low-cost tool that could handle the transactions was needed. It led them to embrace digital is at ion. They started with standalone PCs and migrated to Local Area Network (LAN) connectivity. Core Banking Solution (CBS) platforms followed that transformed branch banking into bank banking. CBS helped banks to provide "anywhere and anytime banking" service to customers. The researcher set out to ascertain the implications of such digital is at ion for bank customers. He interviewed bank officers and bank customers for the purpose. He concluded that digital banking was customer-centric in design and purpose. As a result, banks were in a position to offer an "experience" to their customers as against the "convenience" they offered presently. One such "experience" banks lately offer is worth citing here. To access information about account balance or to receive a mini statement through SMS, all that the

leveraging this advantage banks can afford to raise their rural penetration since they can ensure the financial viability of their rural operations.

KEYWORDS: Book-keeping; CBS; digitalization; leverage; LAN; MIS reporting; SMS; tool

\subsection{INTRODUCTION}

In the late 1980s Indian banks embraced computerisation. They had to improve customer service and tone up book-keeping. Their large customer base was mostly comprised of "low balance" accounts. An effective but low-cost tool that could handle the transactions was needed. It led them to embrace digitalisation. They started with standalone PCs and graduated to Local Area Network (LAN) connectivity and Core Banking Solution (CBS) platforms, in that order, transforming branch banking into bank banking. The penetration of banking services into rural India is still on the low side but mobile penetration is on the higher side. By leveraging this advantage, banks can afford to raise their rural penetration without affecting the financial viability of their rural operations.
\end{abstract} customer has to do is to give a missed call to the bank concerned by dial ling a bank-designated mobile phone number. Another digital product innovation, namely, UPI/Aadhaar-based payments make banking seamless for customers, particularly rural customers, who are not familiar with the English language. Thus, digital is at ion has proved to be positive sum game for all stakeholders. The penetration of banking services into rural India is still on the low side but mobile penetration is on the higher side. By

\subsection{Statement of the problem}

Banks have embraced computerisation and subsequently digitalisation, in slightly various degrees though. They have invested in physical infrastructure and human resources for the purpose. But such investment in itself is not the end. Periodically, the transformation engendered by the investment should be gauged to ascertain if the outlay has translated into outcome. 


\subsection{Review of literature}

1. G Shainesh and Avijit Choudhary in their article study the role of technological changes and advancements in the form of automated teller machines, internet banking, tele-banking, mobile banking, internet banking, etc Invalid source specified. They conclude that reaching the customers through various channels contribute a lot to meet the competitive challenges.

2. China and India boast of the highest percentages (55-60 per cent) of Gen $Y$ and tech-savvy customers that use financial services from nontraditional firms (The Hindu Business Line, 2017). The governments of the two countries continue to prioritise digital initiatives. Hence, the tech-savvy individuals will become more relevant.

3. Affordable, small but powerful computers and other hand-held gadgets and higher Internet bandwidth gradually facilitated easy access to banking products and effortless banking transactions (The Banking \& Finance Post, 2017). The rise of call centres and phone banking services added to customer comfort. A major change in banking practices was facilitated by directing banking transactions through different electronic channels and by helping customers access their bank accounts directly.

\section{$1.4 \quad$ Research gap}

The reviewed literature has not dealt with the review exercise undertaken by the banks, upon digitalisation. It is this gap the present study proposes to bridge.

\subsection{Scope of the present study}

The study confines itself to 60 bank officers (30 from Pr SBs and 30 from PSBs), based in Bangalore (Rural and Urban) districts

\subsection{Objectives of the study}

The objective of the study is to analyse the implications of the digitalisation exercise for banks and their customers

\subsection{Hypothesis proposed to be tested}

The study proposes to test the following hypotheses: "Banks have been more receptive to complaint sand closure of transactions, post digitalisation"

\subsection{Research design}

1.8.1 Research methodology
The study is descriptive in nature and has used the 'fact-finding' survey method

\subsubsection{Sources of data}

Primary data has been collected from 60 bank officers (30 from Pr SBs and 30 from PSBs, based in Bangalore (Rural and Urban) districts

Secondary data has been collected from reputed banking journals, finance journals, magazines and newspapers, in hard and soft versions.

\subsubsection{Sampling plan}

Pr SB officers: Given the limited number of Pr SBs operating in the vicinity where the researcher lives and the time constraint, purposive or judgement sampling under the non-probability method has been employed. Applying a minimum business experience of five years as the criterion, the researcher selected 30 such officers.

PSB officers: Given the limited number of PSBs operating in the vicinity where the researcher lives and the time constraint, purposive or judgement sampling under the non-probability method has been employed. Applying a minimum business experience of five years as the criterion, the researcher selected 30 such officers.

The criteria applied is the most appropriate one for the present study. What is important is the typicality and the relevance of the sampling units to the study and not their overall representativeness to the population. Thus, it guarantees inclusion of the relevant elements in the sample. Probability sampling plans cannot give such a guarantee.

\subsubsection{Data collection instruments}

Interview schedules, specially designed for the purpose, were administered to the respondents for collection of primary data.

\subsubsection{Data processing and analysis plan}

Non-parametric statistical units were used to test the association between qualitative characters and conclusions were drawn on the basis of formation of $\mathrm{H}_{\mathrm{o}}$ and $\mathrm{H}_{1}$.

\subsubsection{Limitations of the study}

Primary data has sometimes been deduced through constant topic-oriented discussions with the 
respondents. Possibly, a certain degree of subjectivity, even if negligible, has influenced their views.

\subsection{Pr SB officers}

In the following paragraphs, the primary data collected from the Pr SB officers is analysed.

\subsubsection{Banks can easily seek out new retail customers, post digitalisation}

Bank scan easily seek out new retail customers, post digitalisation, according to received opinion. Hence the researcher sought to know from the respondents if they agree with the statement that banks can easily seek out new retail customers, post digitalisation. The respondents' agreement / otherwise with the statement is expressed at five levels, namely, Strongly Agree, Agree, Neutral, Disagree and Strongly Disagree. These variates are assigned the values 1, 2, 3, 4 and 5 respectively. Their levels of agreement with the statement are reflected in the following Table and Figure.

Table-1

Banks can easily seek out new retail customers, post digitalisation

\begin{tabular}{|l|l|l|}
\hline $\begin{array}{l}\text { Levels of Agreement } \\
\text { (Values) }\end{array}$ & Frequency & Percentage \\
\hline Strongly Agree (1) & 11 & 37 \\
\hline Agree (2) & 16 & 54 \\
\hline Neutral (3) & 1 & 3 \\
\hline Disagree (4) & 1 & 3 \\
\hline Strongly Disagree (5) & 1 & 3 \\
\hline Total & 30 & 100 \\
\hline
\end{tabular}

Figure-1

Banks can easily seek out new retail customers, post digitalisation

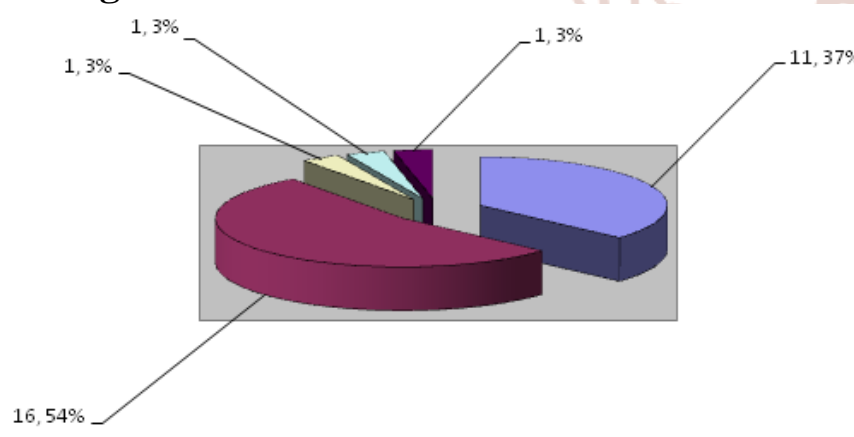

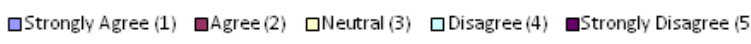

37 percent strongly agree with the statement that banks can easily seek out new retail customers, post digitalisation. 54 percent agree with the statement that banks can easily seek out new retail customers, post digitalisation. Three percent disagree with the statement that banks can easily seek out new retail customers, post digitalisation. Three percent strongly disagree with the statement that banks can easily seek out new retail customers, post digitalisation. Three percent remain neutral.

91 percent agree with the statement that banks can easily seek out new retail customers, post digitalisation.

\subsubsection{Banks can cross-sell financial services easily to existing retail customers, post digitalisation}

According to some, banks can cross-sell financial services easily to existing retail customers, post digitalisation. Hence the researcher sought to know from the respondents if they agree with the statement that banks can cross-sell financial services easily to existing retail customers, post digitalisation. The respondents' agreement / otherwise with the statement is expressed at five levels, namely, Strongly Agree, Agree, Neutral, Disagree and Strongly Disagree. These variates are assigned the values 1, 2, 3, 4 and 5 respectively. Their levels of agreement with the statement are reflected in the following Table and Figure.

Table-2

Banks can cross-sell financial services easily to existing retail customers, post digitalisation

\begin{tabular}{|l|l|l|}
\hline $\begin{array}{l}\text { Levels of Agreement } \\
\text { (Values) }\end{array}$ & Frequency & Percentage \\
\hline Strongly Agree (1) & 9 & 30 \\
\hline Agree (2) & 11 & 37 \\
\hline Neutral (3) & 8 & 27 \\
\hline Disagree (4) & 1 & 3 \\
\hline Strongly Disagree (5) & 1 & 3 \\
\hline Total & 30 & 100 \\
\hline
\end{tabular}

\section{Figure-4.2}

Banks can cross-sell financial services easily to existing retail customers, post digitalisation 


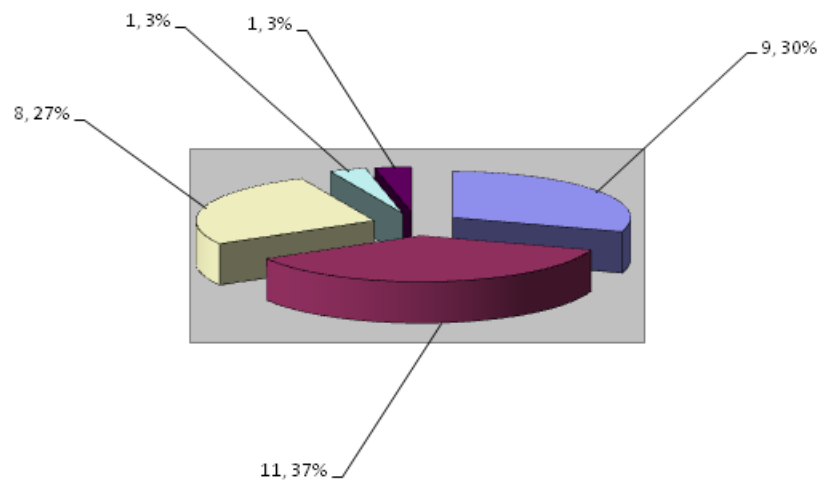

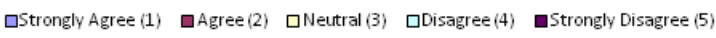

30 percent strongly agree with the statement that banks can cross-sell financial services easily to existing retail customers, post digitalisation.37 percent agree with the statement that banks can crosssell financial services easily to existing retail customers, post digitalisation. Three percent disagree with the statement that banks can cross-sell financial services easily to existing retail customers, post digitalisation. Three percent strongly disagree with the statement that banks can cross-sell financial services easily to existing retail customers, post digitalisation. 27 percent remain neutral.

67 percent agree with the statement that banks can cross-sell financial services easily to existing retail customers, post digitalisation.

\subsubsection{Banks caneasily cross-sell insurance and banking products, post digitalisation}

Additionally, it is said that banks can easily cross-sell insurance and banking products, post digitalisation. Hence the researcher sought to know from the respondents if they agree with the statement that banks can easily cross-sell insurance and banking products, post digitalisation. The respondents' agreement / otherwise with the statement is expressed at five levels, namely, Strongly Agree, Agree, Neutral, Disagree and Strongly Disagree. These variates are assigned the values $1,2,3,4$ and 5 respectively. Their levels of agreement with the statement are reflected in the following Table and Figure.
Table-3

Banks can easily cross-sell insurance and banking products, post digitalisation

\begin{tabular}{|c|c|c|}
\hline $\begin{array}{c}\text { Levels of Agreement } \\
\text { (Values) }\end{array}$ & Frequency & Percentage \\
\hline Strongly Agree (1) & 9 & 30 \\
\hline Agree (2) & 14 & 46 \\
\hline Neutral (3) & 3 & 10 \\
\hline Disagree (4) & 2 & 7 \\
\hline Strongly Disagree (5) & 2 & 7 \\
\hline Total & 30 & 100 \\
\hline
\end{tabular}

Figure-4.3

Banks can easily cross-sell insurance and banking products, post digitalisation

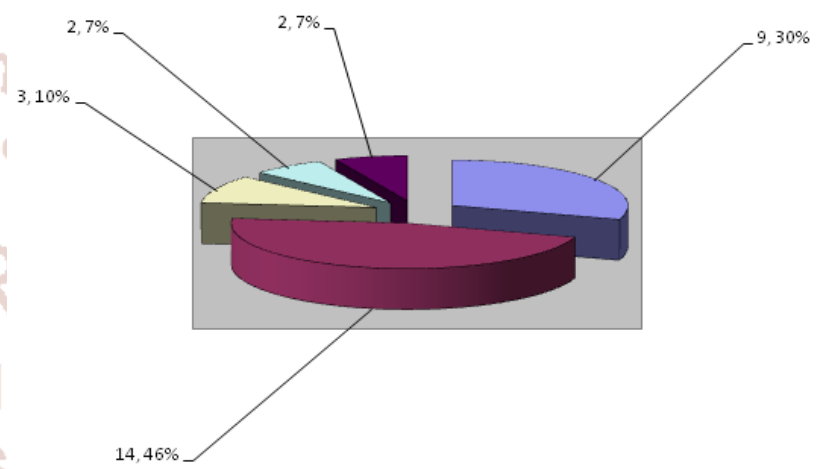

口Strongly Agree (1) घAgree (2) aNeutral (3) 口Disagree (4) aStrongly Disagree (5

30 percent strongly agree with the statement that banks can easily cross-sell insurance and banking products, post digitalisation. 46 percent agree with the statement that banks can easily cross-sell insurance and banking products, post digitalisation. Seven percent disagree with the statement that banks can easily cross-sell insurance and banking products, post digitalisation. Seven percent strongly disagree with the statement that banks can easily cross-sell insurance and banking products, post digitalisation.10 percent remain neutral.

76 percent agree with the statement that banks can easily cross-sell insurance and banking products, post digitalisation.

\subsubsection{Banks find it easier to cultivate younger retail customers, capturing them when they are young, to cross-sell products later on post digitalisation}

According to another view, banks find it easier to cultivate younger retail customers, capturing them when they are young, to cross-sell products later on 
post digitalisation. Hence the researcher sought to know from the respondents if they agree with the statement that banks find it easier to cultivate younger retail customers, capturing them when they are young, to cross-sell products later on post digitalisation. The respondents' agreement / otherwise with the statement is expressed at five levels, namely, Strongly Agree, Agree, Neutral, Disagree and Strongly Disagree. These variates are assigned the values 1,2 , 3, 4 and 5 respectively. Their levels of agreement with the statement are reflected in the following Table and Figure.

\section{Table-4}

Banks find it easier to cultivate younger retail customers, capturing them when they are young, to cross-sell products later on post digitalisation

\begin{tabular}{|l|l|l|}
\hline $\begin{array}{l}\text { Levels of Agreement } \\
\text { (Values) }\end{array}$ & Frequency & Percentage \\
\hline Strongly Agree (1) & 11 & 37 \\
\hline Agree (2) & 14 & 47 \\
\hline Neutral (3) & 3 & 10 \\
\hline Disagree (4) & 1 & 3 \\
\hline Strongly Disagree (5) & 1 & 3 \\
\hline Total & 30 & 100 \\
\hline
\end{tabular}

\section{Figure-4}

Banks find it easier to cultivate younger retail customers, capturing them when they are young, to cross-sell products later on post digitalisation

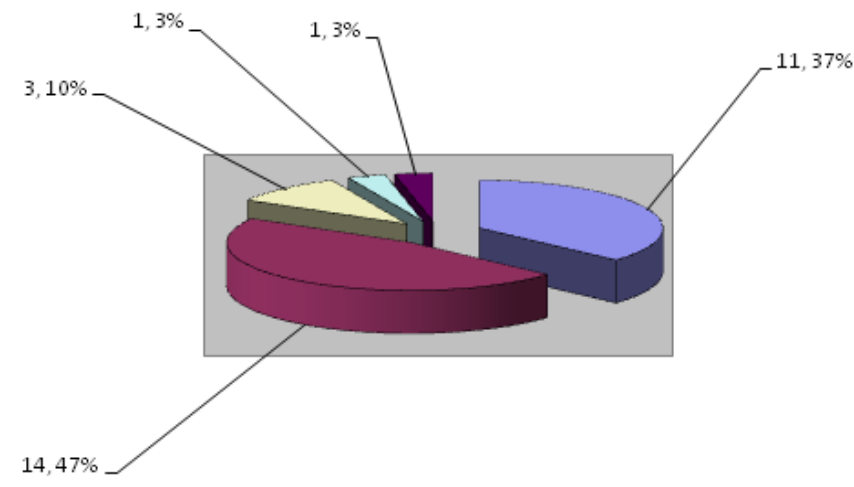

\begin{tabular}{|lll|}
\hline $\begin{array}{l}\text { 口Strongly Agree (1) } \\
\text { 口Disagree (4) }\end{array}$ & $\square$ Agree (2) & $\square$ Neutral (3) \\
\hline
\end{tabular}

37 percent strongly agree with the statement that banks find it easier to cultivate younger retail customers, capturing them when they are young, to cross-sell products later on post digitalisation. 47 percent agree with the statement that banks find it easier to cultivate younger retail customers, capturing them when they are young, to cross-sell products later on post digitalisation. Three percent disagree with the statement that banks find it easier to cultivate younger retail customers, capturing them when they are young, to cross-sell products later on post digitalisation. Three percent strongly disagree with the statement that banks find it easier to cultivate younger retail customers, capturing them when they are young, to cross-sell products later on post digitalisation.10 percent remain neutral.

84 percent agree with the statement that banks find it easier to cultivate younger retail customers, capturing them when they are young, to cross-sell products later on post digitalisation.

\subsubsection{Banks have been more receptive to} complaint sand closure of transactions post digitalisation

According to received opinion, banks have been more receptive to complaint sand closure of transactions post digitalisation. Hence the researcher sought to know from the respondents if they agree with the statement that banks have been more receptive to complaint sand closure of transactions post digitalisation. The respondents' agreement / otherwise with the statement is expressed at five levels, namely, Strongly Agree, Agree, Neutral, Disagree and Strongly Disagree. These variates are assigned the values 1, 2, 3, 4 and 5 respectively. Their levels of agreement with the statement are reflected in the following Table and Figure.

\section{Table-5}

Banks have been more receptive to complaint sand closure of transactions post digitalisation

\begin{tabular}{|c|c|c|}
\hline $\begin{array}{c}\text { Levels of Agreement } \\
\text { (Values) }\end{array}$ & Frequency & Percentage \\
\hline Strongly Agree (1) & 9 & 30 \\
\hline Agree (2) & 11 & 37 \\
\hline Neutral (3) & 4 & 13 \\
\hline Disagree (4) & 3 & 10 \\
\hline Strongly Disagree (5) & 3 & 10 \\
\hline Total & 30 & 100 \\
\hline
\end{tabular}

Figure-5

Banks have been more receptive to complaint sand closure of transactions post digitalisation 


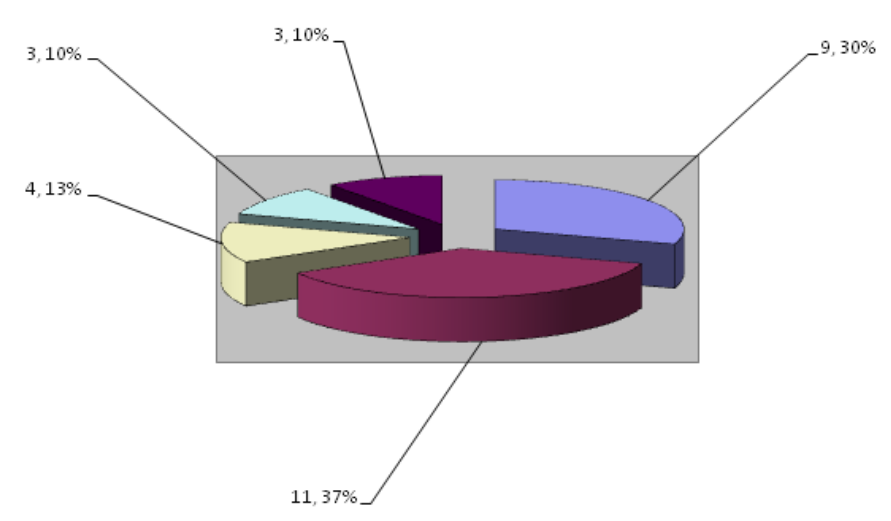

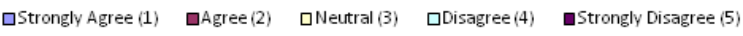

30 percent strongly agree with the statement that banks have been more receptive to complaint sand closure of transactions post digitalisation. 37 percent agree with the statement that banks have been more receptive to complaint sand closure of transactions post digitalisation.10 percent disagree with the statement that banks have been more receptive to complaint sand closure of transactions post digitalisation.10 percent strongly disagree with the statement that banks have been more receptive to complaint sand closure of transactions post digitalisation. 13 percent remain neutral.

67 percent agree with the statement that banks that banks have been more receptive to complaint sand closure of transactions post digitalisation.

\subsection{PSB officers}

In the following paragraphs, the primary data collected from the PSB officers is analysed.

\subsubsection{Banks can easily seek out new retail customers, post digitalisation}

Banks can easily seek out new retail customers, post digitalisation, according to received opinion. Hence the researcher sought to know from the respondents if they agree with the statement that banks can easily seek out new retail customers, post digitalisation. The respondents' agreement / otherwise with the statement is expressed at five levels, namely, Strongly Agree, Agree, Neutral, Disagree and Strongly Disagree. These variates are assigned the values 1, 2, 3, 4 and 5 respectively. Their levels of agreement with the statement are reflected in the following Table and Figure.
Table-6

Banks can easily seek out new retail customers, post digitalisation

\begin{tabular}{|c|c|c|}
\hline $\begin{array}{c}\text { Levels of Agreement } \\
\text { (Values) }\end{array}$ & Frequency & Percentage \\
\hline Strongly Agree (1) & 8 & 27 \\
\hline Agree (2) & 11 & 36 \\
\hline Neutral (3) & 5 & 17 \\
\hline Disagree (4) & 3 & 10 \\
\hline Strongly Disagree (5) & 3 & 10 \\
\hline Total & 30 & 100 \\
\hline
\end{tabular}

\section{Figure-6}

Banks can easily seek out new retail customers, post digitalisation

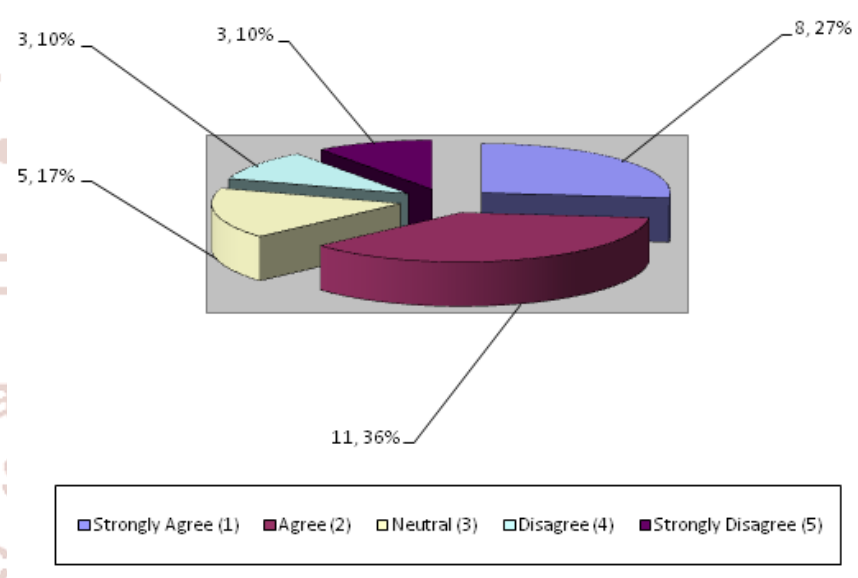

27 percent strongly agree with the statement that banks can easily seek out new retail customers, post digitalisation. 36 percent agree with the statement that banks can easily seek out new retail customers, post digitalisation. 10 percent disagree with the statement that banks can easily seek out new retail customers, post digitalisation. 10 percent strongly disagree with the statement that banks can easily seek out new retail customers, post digitalisation. 17 percent remain neutral.

63 percent agree with the statement that banks can easily seek out new retail customers, post digitalisation.

\subsubsection{Banks can cross-sell financial services easily to existing retail customers, post digitalisation}

Banks can cross-sell financial services easily to existing retail customers, post digitalisation, according to some. Hence the researcher sought to know from the respondents if they agree with the statement that banks can cross-sell financial services easily to existing retail customers, post digitalisation. 
The respondents' agreement / otherwise with the statement is expressed at five levels, namely, Strongly Agree, Agree, Neutral, Disagree and Strongly Disagree. These variates are assigned the values 1,2, 3, 4 and 5 respectively. Their levels of agreement with the statement are reflected in the following Table and Figure.

Table-7

Banks can cross-sell financial services easily to existing retail customers, post digitalisation

\begin{tabular}{|l|l|l|}
\hline $\begin{array}{l}\text { Levels of Agreement } \\
\text { (Values) }\end{array}$ & Frequency & Percentage \\
\hline Strongly Agree (1) & 6 & 20 \\
\hline Agree (2) & 9 & 30 \\
\hline Neutral (3) & 11 & 36 \\
\hline Disagree (4) & 2 & 7 \\
\hline Strongly Disagree (5) & 2 & 7 \\
\hline Total & 30 & 100 \\
\hline
\end{tabular}

Figure-7

Banks can cross-sell financial services easily to existing retail customers, post digitalisation

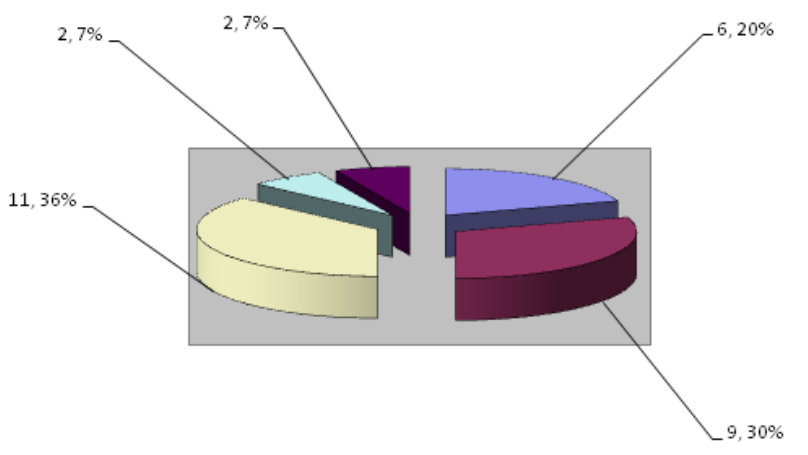

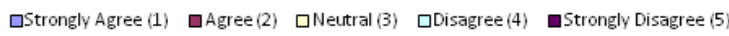

20 percent strongly agree with the statement that banks can cross-sell financial services easily to existing retail customers, post digitalisation. 30 percent agree with the statement that banks can crosssell financial services easily to existing retail customers, post digitalisation. Seven percent disagree with the statement that banks can cross-sell financial services easily to existing retail customers, post digitalisation. Seven percent strongly disagree with the statement that banks can cross-sell financial services easily to existing retail customers, post digitalisation. 36 percent remain neutral.

50 percent agree with the statement that banks can cross-sell financial services easily to existing retail customers, post digitalisation.
1.10.3 Banks can easily cross-sell insurance and banking products, post digitalisation

It is also believed that banks can easily cross-sell insurance and banking products, post digitalisation. Hence the researcher sought to know from the respondents if they agree with the statement that banks can easily cross-sell insurance and banking products, post digitalisation. The respondents' agreement / otherwise with the statement is expressed at five levels, namely, Strongly Agree, Agree, Neutral, Disagree and Strongly Disagree. These variates are assigned the values 1, 2, 3, 4 and 5 respectively. Their levels of agreement with the statement are reflected in the following Table and Figure.

\section{Table-8}

Banks can easily cross-sell insurance and banking products, post digitalisation

\begin{tabular}{|l|l|l|}
\hline $\begin{array}{l}\text { Levels of Agreement } \\
\text { (Values) }\end{array}$ & Frequency & Percentage \\
\hline Strongly Agree (1) & 5 & 17 \\
\hline Agree (2) & 8 & 27 \\
\hline Neutral (3) & 10 & 33 \\
\hline Disagree (4) & 4 & 13 \\
\hline Strongly Disagree (5) & 3 & 10 \\
\hline Total & 30 & 100 \\
\hline
\end{tabular}

\section{Figure-8}

Banks can easily cross-sell insurance and banking products, post digitalisation

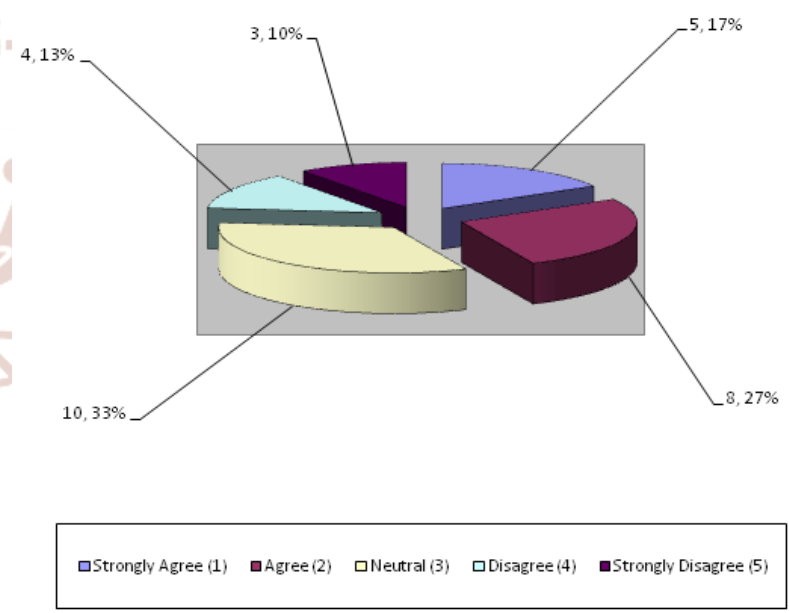

17 percent strongly agree with the statement that banks can easily cross-sell insurance and banking products, post digitalisation. 27 percent agree with the statement that banks can easily cross-sell insurance and banking products, post digitalisation. 13 percent disagree with the statement that banks can easily cross-sell insurance and banking products, post digitalisation. 10 percent strongly disagree with the 
statement that banks can easily cross-sell insurance and banking products, post digitalisation. 33 percent remain neutral.

44 percent agree with the statement that banks can easily cross-sell insurance and banking products, post digitalisation

\subsubsection{Banks find it easier to cultivate younger retail customers, capturing them when they are young, to cross-sell products later on post digitalisation}

Some maintain that banks find it easier to cultivate younger retail customers, capturing them when they are young, to cross-sell products later on post digitalisation. Hence the researcher sought to know from the respondents if they agree with the statement that banks find it easier to cultivate younger retail customers, capturing them when they are young, to cross-sell products later on post digitalisation. The respondents' agreement / otherwise with the statement is expressed at five levels, namely, Strongly Agree, Agree, Neutral, Disagree and Strongly Disagree. These variates are assigned the values $1,2,3,4$ and 5 respectively. Their levels of agreement with the statement are reflected in the following Table and Figure.

\section{Table-9}

Banks find it easier to cultivate younger retail customers, capturing them when they are young, to cross-sell products later on post digitalisation

\begin{tabular}{|l|l|l|}
\hline $\begin{array}{l}\text { Levels of Agreement } \\
\text { (Values) }\end{array}$ & Frequency & Percentage \\
\hline Strongly Agree (1) & 6 & 20 \\
\hline Agree (2) & 8 & 27 \\
\hline Neutral (3) & 6 & 20 \\
\hline Disagree (4) & 6 & 20 \\
\hline Strongly Disagree (5) & 4 & 13 \\
\hline Total & 30 & 100 \\
\hline
\end{tabular}

\section{Figure-9}

Banks find it easier to cultivate younger retail customers, capturing them when they are young, to cross-sell products later on post digitalisation

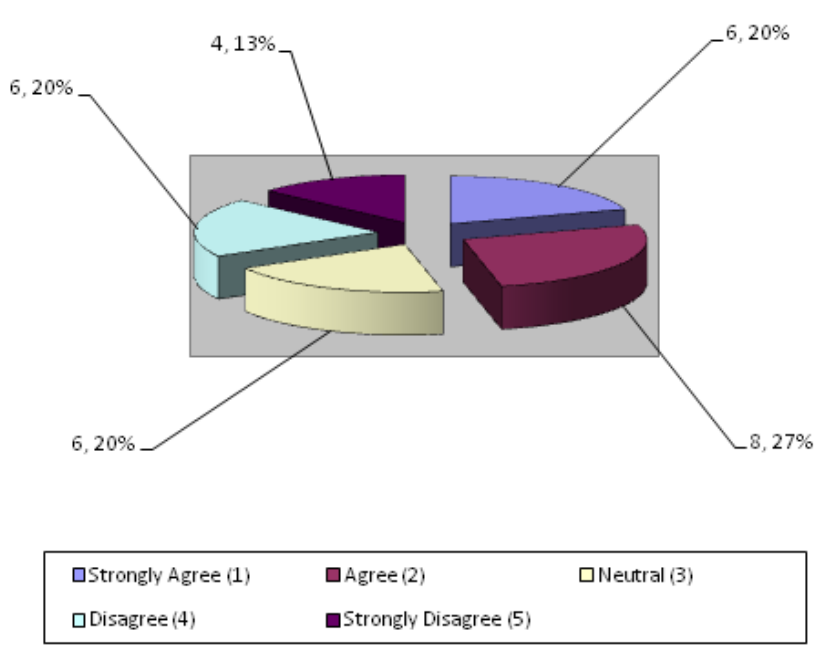

20 percent strongly agree with the statement that banks find it easier to cultivate younger retail customers, capturing them when they are young, to cross-sell products later on post digitalisation.27 percent agree with the statement that banks find it easier to cultivate younger retail customers, capturing them when they are young, to cross-sell products later on post digitalisation. 20 percent disagree with the statement that banks find it easier to cultivate younger retail customers, capturing them when they are young, to cross-sell products later on post digitalisation. 13 percent strongly disagree with the statement that banks find it easier to cultivate younger retail customers, capturing them when they are young, to cross-sell products later on post digitalisation.20 percent remain neutral.

47 percent agree with the statement that banks find it easier to cultivate younger retail customers, capturing them when they are young, to cross-sell products later on post digitalisation

1.10.5 Banks have been more receptive to complaint sand closure of transactions post digitalisation

Received opinion also has it that banks have been more receptive to complaint sand closure of transactions post digitalisation. Hence the researcher sought to know from the respondents if they agree with the statement that banks have been more receptive to complaint sand closure of transactions post digitalisation. The respondents' agreement / otherwise with the statement is expressed at five levels, namely, Strongly Agree, Agree, Neutral, Disagree and Strongly Disagree. These variates are assigned the values 1, 2, 3, 4 and 5 respectively. Their levels of agreement with the statement are reflected in the following Table and Figure. 
International Journal of Trend in Scientific Research and Development (IJTSRD) ISSN: 2456-6470 | IF: 4.101

Table-10

Banks have been more receptive to complaint sand closure of transactions post digitalisation

\begin{tabular}{|l|l|l|}
\hline $\begin{array}{l}\text { Levels of Agreement } \\
\text { (Values) }\end{array}$ & Frequency & Percentage \\
\hline Strongly Agree (1) & 8 & 27 \\
\hline Agree (2) & 9 & 30 \\
\hline Neutral (3) & 8 & 10 \\
\hline Disagree (4) & 3 & 6 \\
\hline Strongly Disagree (5) & 2 & 27 \\
\hline Total & 30 & 100 \\
\hline
\end{tabular}

\section{Figure-10}

Banks have been more receptive to complaint sand closure of transactions post digitalisation

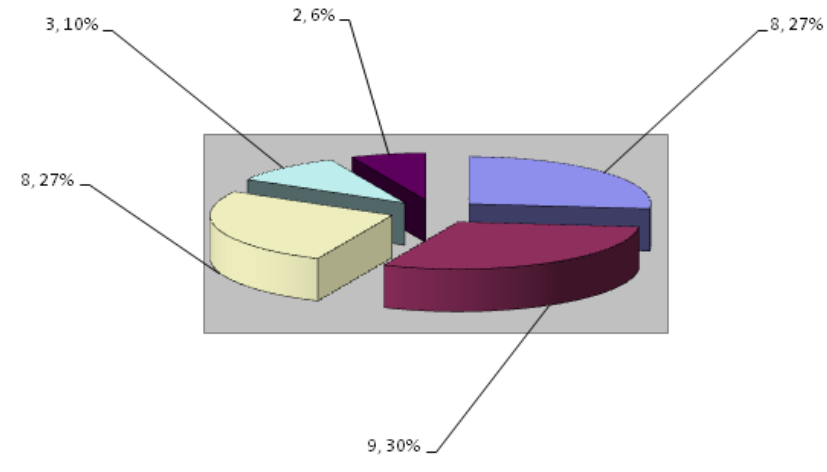

口Strongly Agree (1) घAgree (2) 口Neutral (3) 口Disagree (4) aStrongly Disagree (5)

27 percent strongly agree with the statement that banks have been more receptive to complaint sand closure of transactions post digitalisation. 30 percent agree with the statement that banks have been more receptive to complaint sand closure of transactions post digitalisation. 10 percent disagree with the statement that banks have been more receptive to complaint sand closure of transactions post digitalisation. Six percent strongly disagree with the statement that banks have been more receptive to complaint sand closure of transactions post digitalisation. 27 percent remain neutral.

57 percent agree with the statement that banks that banks have been more receptive to complaint sand closure of transactions post digitalisation.

\subsection{Conclusions}

Conclusions relate to the hypotheses. They are answers to the research questions.

\subsubsection{Hypothesis testing}

\section{Hypothesis}

The following is the hypothesis proposed to be tested: "Banks have been more receptive to complaint sand closure of transactions post digitalisation"

\section{Hence $\mathrm{H}_{0}$ and $\mathrm{H}_{1}$ are as follows:}

$\mathrm{H}_{0}$ :

Banks have not been more receptive to complaint sand closure of transactions post digitalisation

H1:

Banks have been more receptive to complaint sand closure of transactions post digitalisation On the basis of the primary data collected from the respondents, vide

Tables: 5

And 10, a chi-square test was applied to ascertain the association, if any, between the two variables. The following Table reveals the computation made using MS-Excel:

\begin{tabular}{|c|c|c|c|}
\hline & \multicolumn{3}{|c|}{ Observed Values } \\
\hline Category & Yes & No & Total \\
\hline Pr SB officers & 20 & 10 & 30 \\
\hline PSB officers & 17 & 13 & 30 \\
\hline Total & 37 & 23 & 60 \\
\hline & \multicolumn{3}{|c|}{ Expected Values } \\
\hline Category & Yes & No & Total \\
\hline Pr SB officers & 18.5 & 11.5 & 30 \\
\hline PSB officers & 18.5 & 11.5 & 30 \\
\hline Total & 37 & 23 & 60 \\
\hline & Yes & No & \\
\hline o-e & 1.5000 & -1.5000 & \\
\hline & -1.5000 & 1.5000 & \\
\hline (o-e)^2 & 2.2500 & 2.2500 & \\
\hline & 2.2500 & 2.2500 & \\
\hline$\left((\mathrm{o}-\mathrm{e})^{\wedge} 2\right) / \mathrm{e}$ & 0.1216 & 0.1957 & \\
\hline & 0.1216 & 0.1957 & \\
\hline $\mathrm{CV}$ & 0.2432 & 0.3913 & 0.6345 \\
\hline TV & & & 3.8415 \\
\hline $\mathrm{p}$ & & & 0.9591 \\
\hline
\end{tabular}

The calculated value of $\chi^{2}$ is 0.6345 , lower than the table value of 3.8415 for an alpha of 0.05 at one degree of freedom. Hence the alternate hypothesis is rejected, and the null hypothesis is not rejected. 


\subsection{Researcher's recommendations}

1. Banks should exploit the "digitalisation advantage" to augment their customer base; not to tone up only housekeeping.

2. While exploiting the digitalisation-driven crossselling and up selling, banks should neither hard sell nor mis sell their products and services and turn bank sters.

3. Banks have been able to be more receptive to customer grievances in the post digitalisation phase. But there is scope for the banks to be even more receptive to customer grievances and transaction closures.

\subsection{References}

1) Alys, F. (2014, October 29). News: devex.com. Retrieved July 19, 2015, from devex.com Web site: https://www.devex.com/news/india-spioneering-csr-law-could-have-promise-butprogress-is-slow- 84220

2) IANS. (2014, April 3). Companies: The Business Standard. Retrieved July 18, 2015, from The Business Standard Web site: http://www.businessstandard.com/article/companies/india-now-onlycountry-with-legislated-csr-114040300862_1.html

3) India Forbes. (2015, June 24). Blogs: Forbesindia.com. Retrieved July 19, 2015, from Forbesindia.com Web site: http://forbesindia.com/blog/the-goodcompany/the-changing-landscape-of-csr-in-india/

4) The Banking \& Finance Post. (2017, July 23). Home: The Banking \& Finance Post. Retrieved from The Banking \& Finance Post Web site: http://bfsi.eletsonline.com/tech-driven-indianbanking-industry-aiming-for-zenith/

5) The Hindu Business Line. (2017, June 19). Money \& Banking: The Hindu Business Line. Retrieved from The Hindu Business Line Web site: http://www.thehindubusinessline.com/money-andbanking/banking-blues-gen-y-increasingly-optingfor-fintech-services-in-indiachina/article9730675.ece 